\title{
Correction to: Three-dimensional assessment of the sella turcica: comparison between cleft lip and palate patients and skeletal malocclusion classes
}

\author{
Gulsun Akay ${ }^{1}$ Ilkay Eren ${ }^{2} \cdot$ Ozge Karadag $^{3} \cdot$ Kahraman Gungor $^{1}$
}

Published online: 23 May 2020

(c) Springer-Verlag France SAS, part of Springer Nature 2020

\section{Correction to: Surgical and Radiologic Anatomy https://doi.org/10.1007/s00276-020-02481-z}

In the original publication of the article, the given name and family name of the author were swapped. The correct author name is given in this erratum.

The original article was corrected.

Publisher's Note Springer Nature remains neutral with regard to jurisdictional claims in published maps and institutional affiliations.

The original article can be found online at https://doi.org/10.1007/ s00276-020-02481-z.

\section{Gulsun Akay}

akay.gulsun@hotmail.com; gulsunakay@gazi.edu.tr

Ilkay Eren

dt_ilkay@hotmail.com

Ozge Karadag

ozgekaradag@hacettepe.edu.tr

Kahraman Gungor

kahraman@gazi.edu.tr

1 Department of Oral and Dentomaxillofacial Radiology, Faculty of Dentistry, Gazi University, Ankara, Turkey

2 Ministry of Health, Osmanlı Oral and Dental Health Center, Ankara, Turkey

3 Department of Statistics, Graduate School of Science and Engineering, Hacettepe University, Ankara, Turkey 